\title{
LECTURERS' NEED ANALYSIS FOR I-AQRAN MODULE IN ARABIC VOCABULARY CONSOLIDATION AMONG UITM LEARNERS.
}

\author{
${ }^{1}$ Nabihah Yusof, ${ }^{2}$ Harun Baharudin, ${ }^{3}$ Nur Izzah Abdul Malek, ${ }^{4}$ Mohd Isa Hamzah \\ Department of Arabic Education, Faculty of Education Universiti Kebangsaan Malaysia 43600, Bangi Selangor, Malaysia ${ }^{1}$ \\ Department of Arabic Education, Faculty of Education Universiti Kebangsaan Malaysia 43600, Bangi Selangor, Malaysia ${ }^{2}$ \\ Academy of Language Studies (ALS), Universiti Teknologi MARA (UiTM), Kelantan Branch 18500 Machang, Kelantan, \\ Malaysia $^{3}$ \\ Department of Islamic Education, Faculty of Education Universiti Kebangsaan Malaysia 43600, Bangi Selangor, Malaysia ${ }^{4}$ \\ *Corresponding email: harunbaharudin@ukm.edu.my
}

\section{ABSTRACT}

This first-phase of a study known as needs analysis aimed at identifying the needs of Arabic language lecturers in designing and constructing the i - Aqrān Module for strengthening Arabic vocabulary among UiTM students. This needs analysis used survey as its research design and data were then analysed through quantitative approach. The study sample consisted of 40 Arabic language lecturers who teach Arabic II (Two) courses at UiTM in all branch campuses of Malaysia. The study also used a set of questionnaires as research instrument. Before the actual questionnaire was administered to the students, the researcher had consulted insights from 3 referral experts in the field related. The data obtained were analysed by using descriptive statistics in which mean score and standard deviation are generated followed by interpretations of the score. The data were analysed based on 6 constructs: (1) Arabic Language Interactive Learning in the classroom, (2) Interactivity in Arabic Classroom Vocabulary Learning, (3) The Need of Multimedia Software Technology in Interactive Learning, (4) The Need of Skills in Interactive Learning of Arabic language, (5) Proposed Learning Activities based on Multimedia Software Technology in Interactive Learning of Arabic Language and (6) Proposed Forms of Assessment in Interactive Learning of Arabic Language. The findings of the study showed highly positive response from the Arabic Language lecturers towards the 6 constructs listed in the questionnaire. The findings of this needs analysis phase can further solidify the elements that should be included in the designing and constructing of the i - Aqran Module. Needs analysis is an inevitable part or process in designing and building a module (Aliza \& Zamri, 2015).

Keywords: Needs Analysis; Interactive Multimedia; Interactive Learning; Peer; Arabic Vocabulary.

Article Received: 18 October 2020, Revised: 3 November 2020, Accepted: 24 December 2020

\section{Introduction}

Classroom teaching and learning methods are constantly transforming in line with national education policy. System changes not only occur among the primary and secondary education levels which have fully implemented the 21 stcentury learning but also rapidly advancing in higher education institutions (HEIs) level. In term of technological advancement, the future of education integrated with industrial revolution 4.0 will enable extraordinary empowerment of information and knowledge sharing. To meet the needs of this revolution in education, institutions of higher learning must continue to integrate innovative methods to enhance the teaching and learning process (Siti Hajar, 2019). As cited in the mandate from the Minister of Higher Education, (2018), this pedagogical transformation that integrates with Industrial Revolution 4.0 covers heutagogy (self-directed learning), paragogy (peer-assisted learning) and cybergogy (virtualbased learning). Although the concept of the 4.0 industrial revolution was publicly introduced in 2011 in Germany, it is considered as new approach in Malaysia's education system (C.S. Lai, U. Chundra and M.F. Lee, 2020).

Through the digital world, the use of technological innovation drives the advancement of social and daily lifestyle to become easier than ever before. The use of technology has shown a positive impact not only on lifestyle but also has had a positive impact on the field of education (Buasuwan, 2018). In this context, optimizing teaching and learning process to be in line with the educational goals of the industrial revolution 4.0. plays an important factor. Nonetheless, 
lecturers need to have the knowledge and skills in order to fully accustomed to industrial revolution 4.0 elements and work towards implementing them in teaching and learning approach used in the institutions.

Vocabulary learning is one of the biggest challenges in second language learning. This is because learners need to master many words for successful learning. To overcome this challenge, language learners need to use the right method in their language learning (Mohd Zaki \& Kaseh, 2016). Many factors hinder the effectiveness of language teaching and learning especially in vocabulary mastery. Less effective selection of teaching and learning methods has been identified as one of the major contributing factors to the weakness in vocabulary mastery. Failure in choosing interesting and varied teaching and learning methods was also identified as the cause of teaching and learning of the Arabic language that was not for the students and less impactful (Al Muhsin et al., 2020).

Learning method is one of the most important factors influencing students' learning habits or styles. Successful vocabulary learning requires the implementation of self-directed study. Strengthening new or existing Arabic vocabulary imparted in students can be done by focusing on reinforcement aspect with the use of Schmitt Vocabulary Learning Strategy Model (Mohd Zaki \& Kaseh, 2016b). However, students do not use this strategy during vocabulary learning (Nur Fadilah, Mohd Isa \& Harun, 2017).

On another account, according to Ghazali Yusri et al., (2012), the weaknesses of UiTM Arabic language learners can be linked to several factors, one of them is autonomous or self-directed learning method which is applied in teaching and learning process. This view is in line with Nabihah et al., (2019); Noor Anida et al., (2014), who stated that peer learning is one of the methods found under the concept of self-directed learning. Self-directed learning is defined as a student-based learning approach. According to Ayvazo \& Aljadeff-Abergel, (2014); Bowman-
Perrott (2013), there have been many studies that show that peer-assisted learning methods give a positive impact on learners' academic achievement. In addition, researchers use theories that underlie this study such as Learning Theory Vygotsky Theory, (1962), Social Cognitive Theory, (1996) and Theory of Constructivism (Slavin, 2006).

Therefore, within the scope of this study there is still no implementation of interactivity in peerassisted learning. Thus, researchers have taken the initiative to introduce the use of interactivity among peers in strengthening of Arabic vocabulary among UiTM students. The importance of peer interactivity has become the starting point in this study because there is still no study using the i - Aqrān method (peer interactive) that focuses on Arabic language courses at UiTM being conducted.

\section{2. $\quad$ Peer-Assisted Learning}

Peer-assisted learning methods are often being referred to and cited by educators as it improves the quality of learning, contributes to the development of social skills, develops other important skills and provide an emotional benefit to students (Ayvazo \& Aljadeff-Abergel, 2014). According to Bowman-Perrott, (2013), peerassisted learning has been recognized as one of the most innovative teaching methods in recent years. This method has been implemented at every level of education from primary education to higher education. The findings of the study not only improved student performance but also positively impacted social relationships, attitudes and selfesteem among students. This study was supported by Naseerali M.K,. (2013), and added that there were verified studies that peer-assisted learning has often been adopted by educational institutions all around the world and that it has had positive effects on improving academic achievement, enhancing student confidence, shaping the attitudes and interest in the course learned.

A study conducted by Nabihah et al., (2018) on students' perceptions of peer-assisted learning for Arabic vocabulary mastery showed clear findings 
that students gave a positive response or response to the use of peer-assisted learning methods in mastering Arabic vocabulary. This study was conducted on 50 form four students. In addition, the findings also suggested that its implementation can also strengthen Arabic vocabulary among students. On Serap \& Elif, (2016) has conducted a study on the effect of the use of peer-assisted learning on the success of university students, speaking skills and self-efficacy speech in speaking courses. The study used a quasiexperimental research design with a total of 57 study samples in which two groups are formed by a total of 37 students for the control group and a total of 20 students for the treatment group. The findings proved that the use of peer-assisted learning methods shows a positive attitude among students in the treatment group.

In short, based on previous studies on the use of peer-assisted learning methods, it has shown a positive impact on student achievement. In fact, the effectiveness of this method is related to the various issues raised as study subjects for researchers. The progress of research conducted in this area remains a major focus for researchers locally and abroad.

\section{Arabic Vocabulary Learning}

One of the biggest challenges in second language learning is its vocabulary. This is because students need to acquire many vocabularies to succeed in learning (Mohd Zaki \& Kaseh, 2016). According to Abdul Razif Zaini et al., (2016), vocabulary is a fundamental element that needs to be emphasized in language learning. An alternative to the Arabic vocabulary learning is the need to develop applications that are capable of expanding vocabulary among students. According to Fairosnita \& Kamarul Shukri, (2015), having a good command of a language vocabulary can help students to master other language skills. Alternatively, educators need to choose effective teaching and learning methods to stimulate students' motivation. This view is in line with Irma Martiny, Maimun Aqsha \& Zaid, (2017) who asserted that applying the suitable learning method in Arabic vocabulary is one of the main things students should master in learning Arabic. According to Nur Fadilah, Mohd Isa \& Harun, (2017), the use of cognitive strategies in learning Arabic vocabulary should be given priority to enhance the consolidation of existing or newly learned vocabulary. Besides, students need to make use of the cognitive strategies in learning Arabic vocabulary to improve long-term consolidation. This vocabulary-related research trend has highlighted several issues regarding Arabic vocabulary which leads to the implementation of more interesting study designs. Nuraznan et al., (2019) has conducted a study related to the level of basic mastery of Arabic vocabulary. In this study, one of the main aspects is to determine the level of Arabic language proficiency among students, namely from the basic aspects of Arabic vocabulary and Arabic grammar. This study was conducted on Madrasah Tahfiz students around Melaka. The results show that Tahfiz students are able to learn Arabic well based on their mastery level of basic Arabic vocabulary and high mastery level of basic Arabic grammar. This proves that the method of learning Arabic based on the Qur'an can provide guidance to learners and appropriately suit the learners' learning style. This trend of vocabulary studies has sparked high interest in issues pertaining to Arabic vocabulary that led researchers and academicians to diversify and further expand their methods in teaching and learning (Al Muhsin, et al., 2020).

\section{Interactive}

Multimedia-Assisted Learning For Arabic Language

Interactive multimedia is a combination of multimedia elements where the user directly controls the multimedia application and receives direct feedback. It is a system that runs more than just one item at a time such as text, audio, pictures, animations and videos as well as covering user's involvement in terms of giving instructions, controlling and manipulating certain information (Nagavalli, Rozniza, Voon, 2019). According to Siti Zulaidah, Mohamed Nor, Mai 
Shihah, (2017), a teaching process that implements multimedia module is one of the methods that can be used to overcome comprehension problems among students in a particular subject. This method is perceived to be interesting to the learners and encourage them to understand a subject in more depth.

The issue that is a challenge to Arabic language lecturers is that the level of use of Technology in learning Arabic is still in its early stages. Arabic language lecturers need to be more creative and innovative in giving the best to their students (Norhayati, Shaferul Hafes \& Mohd Fauzi, (2013). According to Zahratun Fajriah, (2015), there is an increase in students' Arabic vocabulary performance when an animation is used as the interactive multimedia-assisted learning method. A study was conducted by Nurkhamimi \& Muhammad Sabri Sahri, (2016) on International Islamic University of Malaysia (UIAM) students in using Multimedia Koswer for the teaching of Arabic vocabulary. Eventhough there is no generalization of information can be made based on the findings obtained, some of the study designs and principles of development can be used for the same setting. It is also used as a reference by other institutions which face the same situation and learning issues.

According to Siti Zulaidah, Mohamed Nor Azhari I\& Mai Shihah, (2017), the use of interactive multimedia modules is the best and most effective way of presenting information as it is easy to learn and understand. Moreover, learning theory also supports the use of images, graphics, video and voice to help students understand and remember what they learn. This view is in line withthe opinion of Hashiroh \& Norshuhada, (2017) who stated that the presentation of a lesson using media needs to be more interactive and updated in order to provide an innovative way of presenting creative learning content.

In addition, a study was conducted by Rahmah, (2019) pertaining interactive multimedia which aim is to find out the needs of teachers and students in term of using interactive multimediaassisted learning tool i.e. 3D Aurora Presentation.
This study uses a design and development study approach (DDR). The results of the study were obtained through interviews, observations and documentation. The findings of the study prove that the use of 3D Aurora Presentation as an interactive multimedia assisted learning approach for Arabic writing skills of class V MI is very suitable and helpful.

Based on previous studies conducted, it is proven that the use of interactive multimedia in learning Arabic received a positive response among teachers and students. This is because the combination of text, audio, pictures, animation and video in multimedia do attract them to be engaged passionately in their learning process. In addition, it also encourages active involvement of the learners towards self-directed learning. However, Norhayati, Shaferul Hafes \& Mohd Fauzi (2013) asserted that the use of technology in Arabic language learning is still at beginner's phase and therefore stands as a challenge for the Arabic language lecturers. Educators also need to be more creative and innovative in providing the best learning experience for their students.

\section{The Purpose Of The Study}

The purpose of this study is to identify the needs of the lecturers to design and build the i - Aqrān Module for Arabic vocabulary consolidation among UiTM students. The needs analysis phase is the beginning phase of certain research to take place, in which information about the context and environment of study is gathered. (Aliza \& Zamri 2015). For this study, a needs analysis was conducted at the beginning phase of the module construction to identify the best teaching method in making Arabic vocabulary learning becomes more meaningful and effective. The specific objectives of this study are to (1) analyse the needs of lecturers in designing and constructing the i - Aqrān Module for Arabic vocabulary consolidation among UiTM students. Based on the objectives of the study, this study is also conducted to answer the research questions which are (1) What are the needs of the lecturers in designing and constructing the i - Aqrān Module 
for Arabic vocabulary consolidation among UiTM students?

\section{Research Methodology}

The needs analysis uses survey design and data which were analysed through a quantitative approach. The focus of this study was to carry out the needs analysis in determining the fundamental elements needed in the design and construction phase of i - Aqrān module in which is aimed to strengthen Arabic vocabulary among UiTM students. This study uses an online questionnaire via smartphone in which Google form acts as the response platform among UiTM lecturers. Study sample selected was 40 UiTM Arabic (II) lecturers in Malaysia. These lecturers were selected based on Malaysia's five geographical regions namely northern region, southern region, central region, East Coastal as well as Sabah and Sarawak. A total of 40 lecturers were selected for this study due to the fact they teach Arabic at UiTM branch campuses all over Malaysia.

The general construct of this questionnaire is divided into 2 sections, part A consists of respondent's demographic information, and part B consists of 6 questions involving 5 Likert scales with a scoring method of Strongly Disagree (SD) with a one-point score, Disagree (D) with a twopoint score, Weakly Disagree (WD) with a threepoint score, Agree (A) with a four-point score and Strongly Agree (SA) with a five-point score. The set of questionnaires was developed based on an adaptation and reconstruction from past study questionnaire that had been conducted with an almost similar purpose by Harun Baharuddin (2014); Ghazali Yusri, Nik Mohd Rahimi Nik Yusoff \& Parilah M Shah (2012). Before the actual distribution process of the needs analysis among the respondents, the set of questionnaires were verified and validated by 3 referral experts i.e. a lecturer in Arabic Teaching (e-learning) (USIM), an Arabic Language lecturer (UiTM) and a lecturer in Multimedia Technology Education (UPM). Data obtained from this study is analysed by using descriptive statistics that include mean analysis, percentage and standard deviation.

Therefore, the needs analysis study was conducted to identify the lecturers' needs for the design and construction of the i - Aqrān Module in strengthening Arabic vocabulary among UiTM students. Additionally, it is also meant to select and determine the appropriate content and elements that should be included in the phase of designing and building the i - Aqrān Module as a learning support material for Arabic vocabulary consolidation.

\section{Findings}

Table 1 shows the frequency, percentage, mean, standard deviation and interpretation of the interactive Arabic language learning in the classroom. The overall mean of the five items was (3.84) and standard deviation (0.79) which is at the highest level of mean interpretation. The findings showed that four items are in high-level mean interpretation. Among the items that indicated a high level of mean interpretation were "Students collaborate with peers in completing assignments" (mean $=4.15$, sd $=0.77)$, "Students spend time discussing lessons with peers" ( mean = 3.95 , sd $=0.84)$, "Students dare to express opinion when talking with peers" ( mean $=3.85$, sd $=0.70$ ) and "Students feel comfortable being in a group with peers" $($ mean $=3.83$, sd $=0.84)$. One item indicated a moderate level of interpretation, "Students feel confident in communicating spontaneously with their peers" (mean $=3.45$, sd $=0.84)$.

TABLE 1: Interactive Learning of Arabic Language in the Classroom

(Based on the highest ranking of mean value)

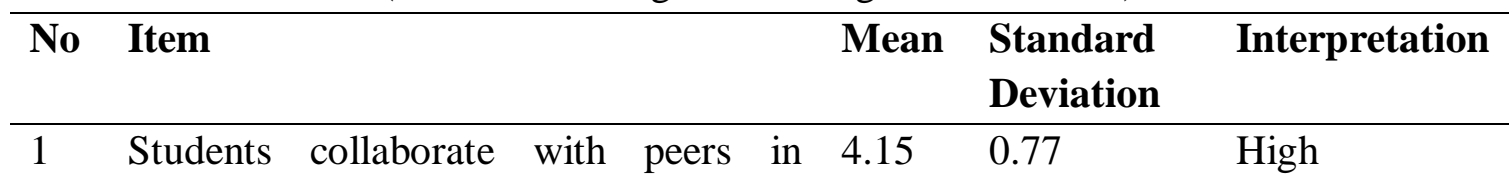




\begin{tabular}{|c|c|c|c|c|}
\hline & completing assignments & & & \\
\hline 2 & $\begin{array}{l}\text { Students spend time discussing lessons } \\
\text { with peers }\end{array}$ & 3.95 & 0.84 & High \\
\hline 3 & $\begin{array}{l}\text { Students dare to express opinion when } \\
\text { communicating with peers }\end{array}$ & 3.95 & 0.84 & High \\
\hline 4 & $\begin{array}{l}\text { Students feel comfortable being in a } \\
\text { group with peers }\end{array}$ & 3.83 & 0.84 & High \\
\hline \multirow[t]{2}{*}{5} & $\begin{array}{l}\text { Students feel confident } \text { in } \\
\text { communicating spontaneously with } \\
\text { their peers }\end{array}$ & 3.45 & 0.84 & Moderate \\
\hline & Overall Mean Value & 3.84 & 0.79 & High \\
\hline
\end{tabular}

Table 2 shows the frequency, percentage, mean, standard deviation and interpretation of interactivity in classroom of Arabic vocabulary learning. The overall mean of the five items was (3.74) and standard deviation (0.83) which is at the highest level of mean interpretation. Based on the findings, there were three items with highlevel interpretation. Among the items that indicated high level interpretation were "Students ask their lecturers to find out the meaning of the new word" ( mean $=4.20$, sd $=0.79$ ), "Students ask their classmates about the meaning of the new word" $($ mean $=3.88$, sd $=0.72)$ and "Students ask the help of Arabic language lecturers to examine the meaning of the new word" $($ mean $=3.88$, $\mathrm{sd}=$ 0.82 ). There were three items related to the interactive learning of Arabic vocabulary in the classroom that demonstrate the moderate interpretation of the mean value, that is, "Students repeatedly pronounce the word aloud with other students" (mean $=3.58$, sd $=0.74)$, followed by the items "Students use mixed spoken words "(mean $=3.45, \mathrm{sd}=1.01)$ and "Students interact using the words learned with other students" with percentage values of Agree (A) and Strongly Agree $($ mean $=3.45$, sd $=0.93)$

TABLE 2: Interactivity in Classroom of Arabic Vocabulary Learning (Based on the highest ranking of mean value)

\begin{tabular}{|c|c|c|c|c|}
\hline No & Item & Mean & $\begin{array}{l}\text { Standard } \\
\text { Deviation }\end{array}$ & Interpretation \\
\hline 1 & $\begin{array}{l}\text { Students ask their lecturers to find out the } \\
\text { meaning of the new word }\end{array}$ & 4.20 & 0.79 & High \\
\hline 2 & $\begin{array}{l}\text { Students ask their classmates about the } \\
\text { meaning of the new word }\end{array}$ & 3.88 & 0.72 & High \\
\hline 3 & $\begin{array}{l}\text { Students ask the help of Arabic language } \\
\text { lecturers to examine the meaning of the } \\
\text { new word }\end{array}$ & 3.88 & 0.82 & High \\
\hline 4 & $\begin{array}{l}\text { Students repeatedly pronounce the word } \\
\text { aloud with other students }\end{array}$ & 3.58 & 0.74 & Moderate \\
\hline 5 & Students use mixed spoken words & 3.45 & 1.01 & Moderate \\
\hline \multirow[t]{2}{*}{6} & $\begin{array}{l}\text { Students interact using the words learned } \\
\text { with other students }\end{array}$ & 3.45 & 0.93 & Moderate \\
\hline & Overall Mean Value & 3.74 & 0.83 & High \\
\hline
\end{tabular}


Table 3 shows the frequency, percentage, mean, standard deviation and interpretation of the need of multimedia technology software in the interactive learning of Arabic language. Findings indicated that the overall mean of the five items was (4.25) and the standard deviation (0.63) which was at the highest level of mean interpretation. In other words, all nine items were at the highest level of mean interpretation. Among the items that indicate high level of mean interpretation were "Learning Websites" (mean = 4.45 , sd $=0.59)$, "Graphics" $($ mean $=4.43$, sd $=$ $0.54)$, "Video/YouTube" ( mean $=4.43, \mathrm{sd}=0.63)$, "Powtoon" ( mean $=4.38$, sd $=0.58)$, "Audio" $($ mean $=4.38, \mathrm{sd}=0.62)$, "Power Point" $($ mean $=$ $4.23, \mathrm{sd}=0.62)$, "Text" $($ mean $=4.15, \mathrm{sd}=0.66)$, "Blog" $($ mean $=4.13, \mathrm{sd}=0.68)$, followed by the "Wiki" item $($ mean $=3.70$, sd $=0.82)$.

TABLE 3: The Need of Multimedia Technology Software in the Arabic Language Interactive Learning.

(Based on the highest ranking of mean value)

\begin{tabular}{lllll}
\hline No & Item & Mean & $\begin{array}{l}\text { Standard } \\
\text { Deviation }\end{array}$ & Interpretation \\
\hline 1 & Learning Websites & 4.45 & 0.59 & High \\
2 & Graphics & 4.43 & 0.54 & High \\
3 & Video/You Tube & 4.43 & 0.63 & High \\
4 & Powtoon & 4.38 & 0.58 & High \\
5 & Audio & 4.38 & 0.62 & High \\
6 & Power Point & 4.23 & 0.62 & High \\
7 & Text & 4.15 & 0.66 & High \\
8 & Blog & 4.13 & 0.68 & High \\
9 & Wiki & 3.70 & 0.82 & High \\
& Overall Mean Value & $\mathbf{4 . 2 5}$ & $\mathbf{0 . 6 3}$ & High \\
\hline
\end{tabular}

Table 4 shows the frequency, percentage, mean, standard deviation and interpretation for the need for skills in Arabic language interactive learning. The results showed that the overall mean value of the five items tested was (4.28) and the standard deviation (0.58) which was at the highest level of mean interpretation. Among the items that indicated high level of interpretation were "Video/YouTube" $($ mean $=4.45, \mathrm{sd}=0.55)$, "Learning Website" (mean $=4.43$, sd $=0.50)$ and "Powtoon" $($ mean $=4.40, \mathrm{sd}=0.54)$, "Blog" $($ mean $=4.33$, sd $=0.57)$ and "Wiki" (mean $=$ $3.83, \mathrm{sd}=0.78)$.

TABLE 4: The Need for Skills in Arabic Language Interactive Learning (Based on the highest ranking of mean value)

\begin{tabular}{lllll}
\hline No & Item & Mean & $\begin{array}{l}\text { Standard } \\
\text { Deviation }\end{array}$ & Interpretation \\
\hline 1 & Video / YouTube & 4.45 & 0.55 & High \\
2 & Learning Websites & 4.43 & 0.50 & High \\
3 & Powtoon & 4.40 & 0.54 & High \\
4 & Blog & 4.33 & 0.57 & High \\
5 & Wiki & 3.83 & 0.78 & High \\
& Overall Mean Value & 4.28 & 0.58 & High \\
\hline
\end{tabular}


Table 5 shows the frequency, percentage, mean, standard deviation and interpretation for proposed learning activities by using multimedia technology in Arabic language interactive learning. The results showed that the overall mean of the five items was (4.49) and the standard deviation (0.55) which was at the highest level of mean interpretation. Among the items that indicated high level interpretation were "Video/YouTube" (mean $=4.58, \mathrm{sd}=0.54)$, "Drilling" $($ mean $=4.50$, $\mathrm{sd}=0.55)$, "Discussion" ( mean $=4.50, \mathrm{sd}=0.55)$, "Feedback Response" ( mean $=4.45$, sd $=0.59)$, and "Tasks" $($ mean $=4.43, \mathrm{sd}=0.54)$.

TABLE 5: Proposed Learning Activities by Using Multimedia Technology in Arabic Language Interactive Learning

(Based on the highest ranking of mean value)

\begin{tabular}{llcll}
\hline No & Item & Mean & $\begin{array}{l}\text { Standard } \\
\text { Deviation }\end{array}$ & Interpretation \\
\hline 1 & Video/You Tube & 4.58 & 0.54 & High \\
2 & Drilling & 4.50 & 0.55 & High \\
3 & Discussion & 4.50 & 0.55 & High \\
4 & Response Feedback & 4.45 & 0.59 & High \\
5 & Tasks & 4.43 & 0.54 & High \\
& Overall Mean Value & $\mathbf{4 . 4 9}$ & $\mathbf{0 . 5 5}$ & High \\
\hline
\end{tabular}

Table 6 shows the frequency, percentage, mean, standard deviation and interpretation for the proposed form of assessment in Arabic language interactive learning. Findings indicated that the overall mean of the five items was (4.33) and the standard deviation (0.79) which was at high-level of interpretations. Among the items that indicated high level interpretation were "Peer Assessment" (mean $=4.48$, sd $=0.64)$, "Interactive Quiz" (mean $=4.43$, sd $=0.64)$, "Objective Test" (mean $=4.43, \mathrm{sp}=0.78)$, "Subjective Test" (mean = 4.23, $\mathrm{sd}=0.83)$, "Final Course Assessment" $($ mean $=4.10, \mathrm{sd}=1.10)$

TABLE 6: Proposed Form of Assessment in Arabic Language Interactive Learning (Based on the highest ranking of mean value)

\begin{tabular}{lllll}
\hline No & Item & Mean & $\begin{array}{l}\text { Standard } \\
\text { Deviation }\end{array}$ & Interpretation \\
\hline 1 & Peer Assessment & 4.48 & 0.64 & High \\
2 & Interactive Quiz & 4.43 & 0.64 & High \\
3 & Objective Test & 4.43 & 0.78 & High \\
4 & Subjective Test & 4.23 & 0.83 & High \\
5 & Final Course Assessment & 4.10 & 1.10 & High \\
& Overall Mean Value & $\mathbf{4 . 3 3}$ & $\mathbf{0 . 7 9}$ & High \\
\hline
\end{tabular}

\section{Discussion}

As transformation of technology occurs, it has also become inevitable for teaching and learning approach applied in today's classroom to also transform. The term "virtual learning" is significantly realized which led to the transformation of an ever-dynamic learning style in the field of education.

Interactive learning is a fun and stimulating way of learning. It also encourages students to be more 
active participators in the classroom. Based on the results obtained from this study, it was found that the mean value recorded is at the highest level when students collaborate with their peers in completing the task. This indicates that students are more likely to choose peers in completing an interactive learning assignment in the classroom. These study findings are supported by the views of Bhavani \& Zamri, (2017), students who are grouped with their peers should practice the value of cooperation and responsibility to help others to understand the concepts that they are learning, and to assist their peers in answering questions whenever he/she gets chosen to represent the group's presentation. Students' sense of responsibility would be polished through the activities carried out by all members of the group, especially when the task assigned to the group holds a specific role to perform as effectively as possible.

For classroom learning, the students chose the lecturers to learn the meaning of a new word that is unfamiliar to them during the teaching and learning session. This is based on the findings that show the highest score of mean level i.e. students ask the lecturer to find out and learn the meaning of the new word. These study findings are supported by views from Irma Martiny, Maimun Aqsha \& Zaid Arafat (2017), in which students spend a large amount of time to search for the meaning of Arabic words by asking their teachers and friends instead of searching for the meaning of the words in the dictionary. Students are perceived as more confident to collaborate with their friends in getting certain information faster than referring to conventional dictionaries.

Interactive multimedia applications are also able to encourage students to be more active and excited throughout their learning session. The students' active involvement in technologyassisted learning can enhance their mastery of Arabic vocabulary. Moreover, the learning sessions would not create a boring environment in the classroom. Based on the results, the mean score of the highest level is the Learning Website. This is in line with the view of (Mohd Noorhadi \&
Zurinah, 2017; Chang, 2001) who asserted that teaching and learning using websites is a means of integrating information and communication technology into the education system. Other than the active participation of students, it can also enhance the level of learning achievement among the students and facilitates the teaching process among lecturers in public universities. The use of online web technology has benefited the teaching and learning strategies in public universities because in a way it creates social interaction relationship between the lecturers and students. The use of online technology has an impact on teaching and learning session as well as students' performance. This is because these internet-based web applications can support teaching and learning in public universities and contributes towards effective implementation of the national education system (Al Muhsin \& Ahmad, 2020).

Apart from that, scholars claimed that online teaching and learning is not only aimed at facilitating lecturers and students but also acts as a platform for transformation towards high quality and effective education. The use of online teaching and learning through websites is an effective practice which emphasises the characteristics of innovative pedagogical practices in which the lecturer's role is to bring innovation to the teaching and learning environment. Conducting online teaching and learning will bring change to students' attitude to becoming more positive and able to learn information literacy skills using the Internet. (Norliza, 2017; Richardson, 2010).

The use of technology in teaching and learning does not only facilitate educators' role and work. Students can also interact and communicate through interactive multimedia learning. This is based on the findings of the study that shows a mean score of the highest level i.e. use of Video/YouTube to master Arabic vocabulary. Video-based learning can attract students as it presents content that students can easily understand and absorb. Video-based lessons is an important element in multimedia because it gives evident impact on the applications used. The use 
of videos that integrates audio, text, images and animation can stimulate students to understand or master the skills they need. Also, the video can be played repeatedly and can easily be accessed on various technology platforms such as computers, mobile phones, tablets and so on from any location. According to W. Marc, (2014), there is a high potential of teachers to be engaged in discussion and collaboration after watching YouTube in microteaching. This method is also excellent to establish professional relationships among teachers.

The use of videos has been implemented in various ways to support learning among students. Video is defined as a media that presents audio and graphics simultaneously. Hence, learning videos can be a medium that helps educators in the teaching and learning process. The study by Shaples, (2000) cited by Syamsulaini \& Mashitoh, (2016), found that video implementation can enhance students' engagement and motivation in learning a certain subject. Therefore, educators need to apply this technology more effectively in their teaching and learning setting as a practical tool to enhance the quality of conventional methods.

The learning environment also plays an important role in a successful learning process to occur. An environment which is built through the help and evaluation of peers among the students themselves will enable a positive impact on the student's selflearning process. Lecturers can also monitor students' engagement in learning. This is based on the findings of this study in which the mean score shows the highest value i.e. peer assessment in terms of assessment for students' vocabulary mastery in the classroom. The findings of this study are in line with Sharon Tighe, Meliosa \& Barbara, (2016) who argued that peer assessment is an 'essential component' in nurturing 'the culture of learning engagement' for a constructive learning environment. Furthermore, peer assessment facilitates the students to participate in several forms of assessment interactions that change the balance of the role and promote control over their learning.
Consequently, as the Education Revolution 4.0 is advancing, it goes in line with student-centered learning. In other words, educators need to put their focus on developing this approach to betterment. In the context of student-centered learning, other than considering the teaching methods, educators also need to consider teaching and learning resources which contain other significant aspects of the teaching and learning process.

\section{Conclusion}

Malaysia is geared to become a developed country while achieving a sophisticated high-quality education system. Hence, the need for educational transformation should be emphasized among the Higher Educational institutions (HEIs) in particular so that a successful benchmark can be set. This is in line with the mandate proposed by the Higher Education Minister (2018) as quoted from MOHE website which is to realize a higher education transformation in line with the Industrial Revolution 4.0. Lecturers need to possess skills and competencies in teaching and learning so that they can be more innovative and act as one of the lead players in education technology among other developed countries.

The findings show that the need for lecturers to design and build modules of i - Aqrān for strengthening Arabic vocabulary is at a positive level. This proves that Arabic language lecturers need more interesting and innovative methods to attract students in learning Arabic vocabulary. This matter coincides with the education goals of the 4.0 industrial revolution which is based on three aspects of pedagogy, namely Heutagogy (self-determination learning, Paragogy (peerassisted learning) and Cybergogy (virtual-based learning).This pedagogical transformation is now more actively applied among students within this year 2020 regardless of their educational level i.e. school level or tertiary level. This is in line with the views of Mohd. Noorhadi \& Zurinah, (2017) who suggest that in this globalised era, pedagogical transformation and information 
sharing should walk in line with the moving time passage, desires and learners' current needs. Technological transformation has given many positive impacts to the students and education system in general. To name a few, it provides opportunity to explore all new information and knowledge in fun way, encourage and motivate students in mastering new knowledge and also nurtures self-learning.

This study do have implications; Firstly, it provides input to Arabic language lecturers in improving the quality of teaching and learning (T\&L) using appropriate methods based on current needs. Secondly, it opens an opportunity for lecturers to pour ideas that can help to improve their teaching quality of Arabic language especially in strengthening Arabic vocabulary among the students. Thirdly, it helps the educational institutions (Academy or Faculty of Arabic Language Studies) to identify their learners' language performance and further refine the teaching and learning aspects. Indirectly, it will also increase the number of target students taking Arabic language courses that excel in academics. Fourthly, it suggests possible courses and teaching workshops that lecturers can attend as they are necessary to strengthen teaching and learning skills among Arabic language lecturers. Lecturers' on-going training is important to encourage lecturers to use methods that are appropriate to the environment and later speed up the transformation of teaching and learning methods that are more up-to-date in the university over time.

In a nutshell, it is hoped that the findings of this study would contribute to improving academic achievement and reducing the dependency on traditional teaching and learning methods in the local universities. It is also important to note that this study gives new exposure to the current teaching and learning methods that integrate important educational elements outlined by Minister of Higher Education (MOHE) as well as effective elements required within Industrial Revolution 4.0.

\section{Acknowledgement}

We gratefully acknowledge the financial support provided by the Geran Dana Penyelidikan FPEND, GG-2019-026

\section{References}

[1] Abdul Razif Zaini, Khirulnizam Abdul Rahman \& Muhammad Haron Husaini. (2016). Pembelajaran Kosa Kata Bahasa Arab Berbantukan Aplikasi. International Conference on Aqidah, Dakwah And Syariah 2016 (IRSYAD2016). Shah Alam 10th May 2016.

[2] Aliza Ali \& Zamri Mahamod. (2015). Analisis Keperluan Terhadap Pengguna Sasaran Modul Pendekatan Berasaskan Bermain bagi Pengajaran Dan Pembelajaran Kemahiran Bahasa KanakKanak Prasekolah. JuKu: Jurnal Kurikulum \& Pengajaran Asia Pasifik Januari 2015, Bil. 3 Isu 1.

[3] Al Muhsin, M. A., Ahmad, N. Z., Sarudin, A., Muhammad, M. M., Othman, Z., Makki, S., \& Kassymoca, G. K. (2020). The Implementation of SCL in Teaching Arabic for Islamic Finance: A Dynamic Approach in Preparing For Education 4.0. International Journal of Psychosocial Rehabilitation. Vol. 24(9). p. 279 - 290.

[4] Al Muhsin, M. A., \& Ahmad, N. Z. (2020). The Emergence of Education 4.0 Trends in Teaching Arabic Islamic Finance Curriculum Design: A Case Study. International Journal of Psychosocial Rehabilitation. Vol. 23(4), p. 1019 - 1031.

[5] Al Muhsin, M. A., Mohd, K. N., Muhammad, M. M., Sarudin, A., Osman, Z., Makki, S., Etigani, M. A. M. A. (2020). THE CHARACTERISTICS OF PROPOSE ARABIC LANGUAGE MODULE FOR THE PURPOSE OF TOURISM: A CASE STUDY ON TOURISTS' MOSQUE IN KUALA LUMPUR. Jounal of Critical Review. Vol. 
7(14), $\quad$ p. $\quad 515 \quad-521, \quad$ DOI: http://dx.doi.org/10.31838/jcr.07.14.89.

[6] Ayvazo S, Aljadeff-Abergel E. (2014). Classwide Peer Tutoring for Elementary and High School Students at Risk: Listening To Students'voices. Support for Learning, 29(1):76-92.

[7] Bhavani Somasundram \& Zamri Mahamod. (2017). Keberkesanan Pembelajaran Koperatif Terhadap Pencapaian dan Motivasi Murid Sekolah Menengah dalam Pembelajaran Bahasa Melayu. Jurnal Pendidikan Bahasa Melayu - JPBM (Malay Language Education Journal - MyLEJ). ISSN: 21804842. Vol. 7, Bil. 1 (Mei 2017): 11-23

[8] Bowman-Perrott L, Davis H, Vannest K, Williams L. (2013). Academic Benefits of Peer Tutoring: A Meta-Analytic Review of Single-Case Research. School Psychol. Rev. 42(1):39-55.

[9] Buasuwan, Prompilai. (2018). Rethinking Thai higher education for Thailand 4.0. Asian Education and Development Studies 7: $157-73$.

[10] C S Lai, U Chundra, and M F Lee. (2020). Teaching and Learning Based on IR 4.0: Readiness of Attitude among Polytechnics Lecturers. Journal of Physics: Conference Series. (2020) 032105. doi:10.1088/17426596/1529/3/032105

[11] Fairosnita binti Ibrahim \& Kamarul Shukri bin Mat Teh. (2015). Pengaruh Permainan Bahasa Terhadap Motivasi Murid Sekolah Rendah Dalam Pembelajaran Perbendaharaan Kata Bahasa Arab. Tinta Artikulasi Membina Ummah . 1(2), 2015 41-50, e-ISSN: 2289-960X.

[12] Ghazali Yusri, Nik Mohd Rahimi, Parilah M. Shah, Wan Haslina Wah \& Ahmed Thalal Hassan. (2012). Penggunaan Strategi Belajar Bersama Rakan dalam Kalangan Pelajar Kursus Bahasa Arab di Universiti Teknologi Mara (UiTM). Asia Pacific Journal of Educators and Education, Vol. 27, 37-50, 2012.
[13] Harun Baharudin. (2014). Strategi Pembelajaran Kosa Kata Bahasa Arab Pelajar Sekolah Menengah Agama di Malaysia Unpublished Ph.D thesis,University Malaya, Kuala Lumpur, Malaysia.

[14] Hashiroh Hussain \& Norshuhada Shiratuddin. (2017). Persepsi Pereka Bentuk (Guru) Terhadap Kualiti Garis Panduan Pembangunan Media Pengajaran Berkonsepkan Penceritaan Digital untuk Tablet Skrin Sentuh. Malaysian Journal of Learning and Instruction (MJLI), 14 (2), 271-292.

[15] Irma Martiny Md Yasim, Maimun Aqsha Lubis \& Zaid Arafat Mohd Noor. (2017). Penggunaan Teknik Pembelajaran Aspek Kosa Kata Bahasa Arab dalam Kalangan Murid. ASEAN Comparative Education Research Journal on Islam and Civilization (ACER-J), Volume 1(1) January 2017, 14-24.

[16] Mohd. Noorhadi Mohd. Yusof \& Zurinah Tahir. (2017). Kepentingan Penggunaan Media Sosial Teknologi Maklumat dalam Pendidikan IPTA. Journal of Social Sciences and Humanities. Vol. 12, No. 3 (2017), 023 ISSN: 1823-884x

[17] Mohd Zaki Ismail \& Kaseh Abu Bakar. 2016. Strategi Pembelajaran Kosa Kata Berimbuhan Bahasa Arab. Malaysian Journal of Learning and Instruction (MJLI). Vol. 13 (2016): 113-133.

[18] Nabihah Yusof, Harun Baharudin , Maimun Aqsha Lubis \& Muhammad Saiful Anuar Yusoff. (2018). Persepsi Pelajar Terhadap Penggunaan Kaedah Bimbingan Rakan Sebaya (Brs) untuk Pembelajaran Kosa Kata Arab, $e$ Academia Journal, e-ISSN: 2289-6589. Volume 7 Issue 2 2018, 66-75.

[19] Nabihah Yusof, Harun Baharudin, Nik Mohd Rahimi Nik Yusoff \& Aisyah Sjahrony. 2019. I - Aqran Module Construction For Arabic Vocabulary Consolidation: A Needs Analysis. 
Religación Revista De Ciencias

Sociales Y Humanidades. Vol 4. No 21.

Quito Trimestral Número Especial

Noviembre 2019pp. 57 - 65. ISSN 24779083.

[20] Nagavalli Poobalan1, Rozniza Zaharudin, Voon Yeun Ting. (2019). Penggunaan Bahan Multimedia Interaktif 3D Animasi ('Scratch') Dalam Kaedah Pembelajaran Teradun Terhadap Minat Dan Pencapaian Murid Tahun 5 Bagi Mata Pelajaran Sains. Jurnal Pendidikan Sains \& Matematik Malaysia. Vol 9 No.1 Jun 2019 / ISSN 2232-039/ eISSN 2600-9307.

[21] Noor Anida Awang, Rahimah Embong, Zaiton Mustafa \& Azhar Yaacob.(2014). Strategi Pembelajaran Bersama Rakan Sebaya Untuk Meningkatkan Kemahiran Bertutur Bahasa Arab Dalam Kalangan Pelajar Bukan Penutur Jati Di Unisza. Prosiding Seminar Pengajaran \& Pembelajaran Bahasa Arab. Fakulti Pengajian Islam, UKM \& Fakulti Kontemporari Islam, Unisza.

[22] Norhayati Che Hat, Shaferul Hafes Sha'ari \& Mohd Fauzi Abdul Hamid. (2013). Persepsi Pelajar Terhadap Penggunaan Animasi dalam Pembelajaran Bahasa Arab. Jurnal Teknologi (Social Sciences). 63:1 (2013), 25-29.

[23] Norliza Hussin. (2017). Penggunaan Laman Web Sebagai Transformasi dalam Pengajaran dan Pembelajaran Pendidikan Islam. O-JIE: Online Journal of Islamic Education. [S.1.], v. 1, n. 2, aug. 2017. ISSN 2289-3016.

[24] Nuraznan Jaafar Mohd Zahimie Mohd Dzahid Noor Adawiyah Ahmad Radzi Akmarina

[25] Mohd Salwai. (2019). Hubungan Antara Tahap Penguasaan Asas Kosa Kata Arab Dan Tatabahasa Arab Dalam Kalangan Pelajar Madrasah Tahfiz Sekitar Melaka. Jurnal Kesidang . Volume 4 2019: 53-62.

[26] Nur Fadilah Abdul Basit. Mohd Isa Hamzah \& Harun Baharudin. (2017).
Strategi Kognitif dalam Pembelajaran Kosa Kata Bahasa Arab. Journal of Advanced Research in Social and Behavioural Sciences. Issue 1 (2017) 4151. ISSN: 2462-1951.

[27] Nurkhamimi Zainuddin \& Muhammad Sabri Sahrir. 2016. Multimedia Courseware for Teaching Arabic Vocabulary: Let's Learn from the Experts. Universal Journal of Educational Research, 4(5): 1167-1172, 2016.

[28] Rahmah Khaerotin. (2019). Pengembangan Multimedia Interaktif $3 D$ Aurora Presentation untuk Keterampilan Menulis Bahasa Arab. al Mahāra Jurnal Pendidikan Bahasa Arab. Vol. 5, No. 1, Juni 2019/1440H P-ISSN: 2477-5835/EISSN: 2477-5827.

[29] Serap Uzuner Yurt1 \& Elif Aktaş. (2016). The effects of peer tutoring on university students' success, speaking skills and speech self-efficacy in the effective and good speech course. Academic Journals: Educational Research and Reviews. Vol. 11(11), pp. 1035-1042, 10 June, 2016. ISSN 1990-3839.

[30] Sharon Tighe-Mooney, Meliosa Bracken \& Barbara Dignam. 2016. Peer Assessment as a Teaching and Learning Process: The Observations and Reflections of Three Facilitators on a First-Year Undergraduate Critical Skills Module. All Ireland Journal of Higher Education. AISHE-J Volume 8 Number 2 (Summer 2016) 2831.

[31] Siti Hajar Halili.(2019). Technological Advancements In Education. The Online Journal of Distance Education and eLearning. January 2019 Volume 7, Issue 1.

[32] Siti Zulaidah Salsidu, Mohamed Nor Azhari Azman \& Mai Shihah Abdullah. (2017). Tren Pembelajaran Menggunakan Multimedia Interaktif dalam Bidang Pendidikan Teknikal: Satu Sorotan Literatur. Sains Humanika 9: 1-5 (2017) 135-141. 
[33] Syamsulaini Sidek \& Mashitoh Hashim. 2016. Pengajaran Berasaskan Video dalam Pembelajaran Berpusatkan Pelajar: Analisis dan Kajian Kritikal. Journal of ICT in Education (JICTIE) ISSN 22897844 / Vol. 3 / 2016 / 24-33.

[34] W. Marc Jackman. (2014). Students' Perspectives on YouTube Video Usage as an E-Resource in the University Classroom. J. Educational Technology Systems. Vol. 42(3) 273-297, 2013-2014.

[35] Zahratun Fajriah. (2015). Peningkatan Penguasaan Kosakata Bahasa Arab (Mufradat) Melalui Penggunaan Media Kartu Kata Bergambar (Penelitian Tindakan Pada Siswa kelas I MI Nurul HakimKediri Lombok Barat Tahun 2015). Jurnal Pendidikan Usia Dini. Volume 9 Edisi1, April 2015. 